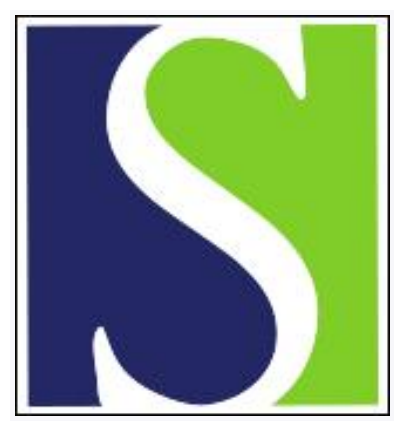

Scand J Work Environ Health 1991;17(6):409-413

https://doi.org/10.5271/sjweh.1685

Issue date: Dec 1991

Symptoms, airway physiology and histology of workers exposed to medium-density fiber board.

by Holmstrom M, Rosen G, Wilhelmsson B

Affiliation: Department of Oto-Rhino-Laryngology, Huddinge University Hospital, Sweden.

This article in PubMed: www.ncbi.nlm.nih.gov/pubmed/1788535

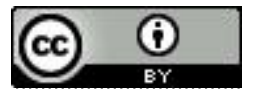




\title{
Symptoms, airway physiology and histology of workers exposed to medium-density fiber board
}

\author{
by Mats Holmström, MD, ${ }^{1}$ Gunnar Rosén, $\mathrm{PhD},{ }^{2}$ Bo Wilhelmsson, $\mathrm{MD}^{3}$
}

\begin{abstract}
HOLMSTRÖM M, ROSÉN G, WILHELMSSON B. Symptoms, airway physiology and histology of workers exposed to medium-density fiber board. Scand J Work Environ Health 1991;17:409-13. Mediumdensity fiber (MDF) board was recently introduced in the furniture industry. In this pilot study health complaints, physiology, and histology of the upper airways were evaluated for two groups of workers, one handling MDF board for at least one-third of their work week (MDF group) and another handling traditional fiber board. Civil servants served as a reference group. The frequency of health complaints concerning the airways was higher, the sense of smell was poorer, and the frequency of nasal obstruction measured with rhinomanometry was higher for the MDF group, while mucociliary activity was lower in the group handling traditional board. In both groups forced vital capacity was low when compared with expected values. Histological specimens from the middle turbinate of the nose showed, in a few cases, nasal epithelial dysplasia in the traditional board group, but histological changes in terms of scoring did not differ significantly between the groups.
\end{abstract}

Key terms: formaldehyde, nasal histology, nasal irritants, nasal physiology, wood dust.

Health complaints such as nasal obstruction and rhinorrhea, in addition to impaired physiological variables such as nasal patency, nasal mucociliary function and lung volumes, have been reported for workers exposed to wood dust (1). Histological changes in nasal mucosa have been described (2), and there is a risk of developing sinonasal carcinomas, especially after exposure to fine particle dust from hard wood such as beech and oak (3).

Discomfort in the airways after exposure to formaldehyde has been described by several authors (4). The effects of combined exposure to wood dust and formaldehyde on nasal function and nasal mucosa were recently described and found to be much the same as after exposure to pure wood dust $(5,6)$.

During the last decade the use of medium-density fiber (MDF) board has been increasing in the furniture industry. MDF board looks like traditional board (Masonite ${ }^{\circledR}$ ) but is lighter and has shorter fibers. The thickness is usually $10 \mathrm{~mm}$ or more. MDF board consists of wood fibers and carbamide resin glue, containing formaldehyde. It has advantages over wood in that it is homogeneous and there are fewer knots. It is cheaper to work with since it can be surface-treated immediately and needs no veneer. MDF board is used for profiled furniture and doors, for cupboards with rounded edges, and table tops with profiled edges. Its use is likely to increase.

1 Department of Oto-Rhino-Laryngology, Huddinge University Hospital, Huddinge, Sweden.

2 National Institute of Occupational Health, Solna, Sweden.

${ }^{3}$ Department of Oto-Rhino-Laryngology Västerås County Hospital, Västerås, Sweden.

Reprint requests to: Dr M Holmström, Department of OtoRhino-Laryngology, Huddinge University Hospital, S-141 86 Huddinge, Sweden.
There are few reports in the literature concerning the health risks of MDF. Eye, nose, and skin complaints have been reported among workers sanding, milling, shaping, and molding MDF board $(7,8)$, but there have been no reports concerning airway physiology or histology.

This pilot study was thus performed to investigate whether symptoms, airway physiology, and nasal histological changes differed among workers exposed to MDF and those exposed to dust from traditional board and pure wood.

\section{Subjects and methods}

This was a cross-sectional study, and the participants were not aware that the health effects of MDF were its target. Two groups of workers and a reference group were examined. One group consisted of 16 workers exposed to MDF dust for more than one-third of their workday (MDF group). Twelve of the 16 men had worked with MDF board for two years or more. The other group consisted of 29 workers exposed to other sorts of wood dust, but not to MDF. The third group was a reference group of 36 persons, most of whom were civil servants from the same village as the exposed workers. The percentage of smokers was 38,31 , and 28 for the MDF group, the wood dust group and the referents, respectively. The male to female ratio was $16: 0,25: 4$, and $17: 19$ for the three groups, respectively. The mean age of the groups was $44.1,39.3$, and 39.9 , respectively. The mean time of employment with occupational exposure to wood dust was 18.4 years for the MDF group and 13.7 years for the wood dust group. 
The workers in both exposed groups were occupied with the mechanical treatment of wood, for example, milling, sawing, sanding, and drilling. In addition to the MDF exposure in the MDF group, the used material was mainly particle board and hard wood such as birch and beech in both groups. In both groups the exposure levels to wood dust and formaldehyde were considered fairly stable according to several measurements taken over a period of one year with both personal and stationary equipment, techniques described elsewhere (6).

The examinations were performed on three different days in the subjects' workplaces. A questionnaire was thoroughly checked by one of the authors in connection with a medical examination The medical examination itself focused on the ear, nose, and throat.

Anterior rhinomanometry was performed according to Kumlien \& Schiratzki (9), pressure drop and airflow being recorded during inhalation. The nasal volume flow rate, estimated from the angle of the nasal breathing flow curve $\left(\mathrm{v}_{2}\right)$, was determined before and after decongestion with an oxymethazoline spray according to Broms et al (10).

Mucociliary clearance was tested with measurements of the transport time of Cardiogreen ${ }^{\circledR}$, placed on both inferior turbinates $1 \mathrm{~cm}$ behind the anterior border to the rhinopharynx. When the transport time exceeded $20 \mathrm{~min}$, it was considered pathological.

The olfactory threshold was tested with a series of binary pyridine dilution steps, as described by Amoore \& Ollman (11).

Spirometry was carried out with a vitalograph (Vitalograph Ltd, England), and the forced vital capacity (FVC) and forced expiratory volume in $1 \mathrm{~s}$ $\left(\mathrm{FEV}_{1.0}\right)$ were measured as the best of at least three efforts. The individual values were compared with the expected normal values (based on age, gender, height, and weight) (12).

For the histological examination a nasal biopsy was taken, after local anesthesia with a cotton pellet soaked in lidocaine $(3.4 \%)$ and naphazolin $(0.02 \%)$, from the medial or inferior aspect of the middle turbinate, where deposition of wood dust and absorption of formaldehyde is mainly localized.

The histological changes of the nasal epithelium were classified according to the scoring system of Torjusen et al (13), between 0 and 8 , where $0=$ normal respira-

Table 1. Exposure to wood dust and formaldehyde in three cases from the medium-density fiber (MDF) and wood dust groups during comparable work tasks. The measures were based on whole-day samples for wood dust. The sampling time for formaldehyde was $1 \mathrm{~h}$ or longer.

\begin{tabular}{lcccccc}
\hline & \multicolumn{2}{c}{ MDF group } & & \multicolumn{2}{c}{ Wood dust group } \\
\cline { 2 - 3 } & $\begin{array}{c}\text { Wood } \\
\text { dust } \\
\left(\mathrm{mg} / \mathrm{m}^{3}\right)\end{array}$ & $\begin{array}{c}\text { Form- } \\
\text { aldehyde } \\
\left(\mathrm{mg} / \mathrm{m}^{3}\right)\end{array}$ & & $\begin{array}{c}\text { Wood } \\
\text { dust } \\
\left(\mathrm{mg} / \mathrm{m}^{3}\right)\end{array}$ & $\begin{array}{c}\text { Form- } \\
\text { aldehyde } \\
\left(\mathrm{mg} / \mathrm{m}^{3}\right)\end{array}$ \\
\cline { 2 - 3 } & 3.6 & 0.48 & & 1.0 & 0.34 \\
Fitting/sanding & 0.8 & 0.30 & & 0.3 & 0.08 \\
Sawing & 3.8 & 0.17 & & 0.7 & 0.17 \\
Sanding & & & & &
\end{tabular}

tory epithelium, $1=$ stratified cuboidal, $2=$ mixed stratified cuboidal/squamous, $3=$ stratified squamous, $4=$ stratified squamous with marked horny layer, $5=$ stratified squamous with marked horny layer and budding of the epithelium, $6=$ light epithelial dysplasia, $7=$ severe epithelial dysplasia, and $8=$ cancer.

In the analysis of the questionnaire results the rate differences (with the $95 \%$ confidence intervals) were estimated, and for the histological results the MannWhitney U-test was used. For the physiological variables Student's t-test was used. The differences were classified as significant if the $\mathbf{P}$-value was $<0.05$.

\section{Results}

The mean personal exposure to wood dust in both the MDF and wood dust group was $1-2 \mathrm{mg} / \mathrm{m}^{3}$, and even higher during grinding. The mean exposure level to wood dust was $1.4 \mathrm{mg} / \mathrm{m}^{3}$ for both groups according to several measurements made over a period of one year. Personal exposure to formaldehyde during the year was also fairly stable for both groups, between 0.2 and $0.3 \mathrm{mg} / \mathrm{m}^{3}$, peak values seldom being higher than $0.5 \mathrm{mg} / \mathrm{m}^{3}$. The mean exposure to formaldehyde was $0.25 \mathrm{mg} / \mathrm{m}^{3}$ for the wood dust group and $0.26 \mathrm{mg} / \mathrm{m}^{3}$ for the MDF group. In the office of the reference group the mean exposure to formaldehyde over a period of one year was $0.09 \mathrm{mg} / \mathrm{m}^{3}$. In a few cases the whole-day exposure levels to wood dust and formaldehyde were estimated. Thus, when exposure samples from three workers in each group with comparable tasks were collected and compared, the levels of wood dust varied between 0.8 and $3.6 \mathrm{mg} / \mathrm{m}^{3}$ in the MDF group, and between 0.3 and $1.0 \mathrm{mg} / \mathrm{m}^{3}$ in the wood dust group (table 1). The exposure to formaldehyde varied between 0.17 and $0.48 \mathrm{mg} / \mathrm{m}^{3}$ in the MDF group and between 0.08 and $0.34 \mathrm{mg} / \mathrm{m}^{3}$ in the wood dust group.

The dust particles did not vary in size between the different factories investigated. Most of the particles were less than $10 \mu \mathrm{m}$ in diameter (table 2), and there was no difference in particle size during work with MDF board. The mass size distribution of the wood dust particles and the weight median analyses of wood dust were in the same range during work with both the MDF board and traditional board and pure wood, all the samples ranging between 16.5 and $19.9 \mu \mathrm{m}$.

In the questionnaire nasal symptoms related to the workplace were frequent for both of the exposed groups, but there was, however, a strong overrepresentation of symptoms from the nose in the MDF group (for 15 of the 16 workers, $94 \%$ ) in comparison with the wood dust group (for 9 of the 29 workers, $31 \%$ ). Nasal obstruction, watery discharge, nasal itching, and a decreased sense of smell were the main complaints in the MDF group (table 3). Other symptoms found more often in the MDF group than in the wood dust group and related to the workplace were throat discomfort, eye and skin problems (itching and eczema), 
and discomfort from the lower airways (ie, bronchial and pulmonary symptoms). None of the registered symptoms were more common in the wood dust group than in the MDF group. Most of the workers with work-related symptoms experienced relief during the weekends, 12 of $15(80 \%)$ in the MDF group and 6 of $9(67 \%)$ in the wood dust group. During vacations all 15 persons with work-related symptoms in the MDF group were relieved from symptoms and seven of nine $(78 \%)$ in the wood dust group.

The medical examination did not disclose any ear, nose, or throat differences between the groups. Wood dust was often seen outlining the mucosa of the anterior septal wall and middle meatus in both groups.

In the wood dust group rhinomanometry disclosed a mean $v_{2}$ value of 21.0 before decongestion and a corresponding value of 13.4 after decongestion. In the MDF group the corresponding values were 22.6 and 14.0 , respectively (table 4$)$. The difference between the $\mathrm{v}_{2}$ values before and after decongestion, as a measure of nasal resistance, was thus higher in the MDF group and therefore indicated more mucosal swelling in this group. Nasal swelling was, however, more pronounced in the wood dust group than in the reference group.

Table 2. Percentages of wood dust particles distributed by maximum diameter and the type of work.

\begin{tabular}{lccccc}
\hline Measuring point & $\begin{array}{c}1-5 \mu \mathrm{m} \\
(\%)\end{array}$ & $\begin{array}{c}6-10 \mu \mathrm{m} \\
(\%)\end{array}$ & $\begin{array}{c}11-15 \mu \mathrm{m} \\
(\%)\end{array}$ & $\begin{array}{c}16-20 \mu \mathrm{m} \\
(\%)\end{array}$ & $\begin{array}{c}>21 \mu \mathrm{m} \\
(\%)\end{array}$ \\
\hline $\begin{array}{l}\text { Work with pure wood and particle board } \\
\text { Cutting beech-veneered particle board }\end{array}$ & 91 & 6 & 1 & 0 & 1 \\
Work with medium -density fiber board $^{\mathrm{b}}$ & 85 & 9 & 3 & 1 & 2 \\
Work with medium-density fiber board $^{\mathrm{a}}$ & 82 & 9 & 4 & 3 & 2 \\
\hline
\end{tabular}

a The samples were taken with stationary equipment.

b The samples were taken with personal samplers.

Table 3. Symptoms experienced by workers handling medium density fiber board (MDF group) and by those working with traditional fiber board (wood dust group) and by the referents. ( $95 \% \mathrm{Cl}=95 \%$ confidence interval)

\begin{tabular}{|c|c|c|c|c|c|c|c|c|c|c|}
\hline & \multicolumn{2}{|c|}{$\begin{array}{l}\text { MDF group } \\
(N=16)\end{array}$} & \multicolumn{2}{|c|}{$\begin{array}{l}\text { Wood dust } \\
\text { group } \\
(N=29)\end{array}$} & \multicolumn{2}{|c|}{$\begin{array}{l}\text { Reference } \\
\text { group } \\
(\mathbb{N}=36)\end{array}$} & \multicolumn{2}{|c|}{$\begin{array}{l}\text { MDF-reference } \\
\text { group }\end{array}$} & \multicolumn{2}{|c|}{$\begin{array}{l}\text { Wood dust- } \\
\text { reference group }\end{array}$} \\
\hline & $\mathbf{N}$ & $\%$ & $\mathbf{N}$ & $\%$ & $\mathrm{~N}$ & $\%$ & $\begin{array}{c}\text { Rate } \\
\text { differ- } \\
\text { ence } \\
(\%)\end{array}$ & $95 \% \mathrm{Cl}$ & $\begin{array}{c}\text { Rate } \\
\text { differ- } \\
\text { ence } \\
(\%)\end{array}$ & $95 \% \mathrm{Cl}$ \\
\hline Nasal discomfort & 15 & 94 & 9 & 31 & 10 & 28 & 66 & $47-85$ & 3 & $-20-26$ \\
\hline $\begin{array}{l}\text { Nasal obstruction } \\
\text { Watery discharge } \\
\text { Nasal itching } \\
\text { Impaired sense of smell }\end{array}$ & $\begin{array}{l}6 \\
4 \\
3 \\
7\end{array}$ & $\begin{array}{l}40 \\
27 \\
20 \\
44\end{array}$ & $\begin{array}{r}5 \\
5 \\
-2\end{array}$ & $\begin{array}{r}17 \\
17 \\
0 \\
7\end{array}$ & $\begin{array}{l}4 \\
2 \\
3 \\
2\end{array}$ & $\begin{array}{r}11 \\
6 \\
8 \\
6\end{array}$ & $\begin{array}{l}27 \\
19 \\
11 \\
38\end{array}$ & $\begin{array}{r}0.5-52 \\
-3-24 \\
-11-32 \\
13-64\end{array}$ & $\begin{array}{r}6 \\
11 \\
-8 \\
1\end{array}$ & $\begin{array}{l}-11-23 \\
-4-27 \\
-16-6 \\
-11-13\end{array}$ \\
\hline Eye discomfort & 7 & 44 & 2 & 7 & 2 & 6 & 38 & $13-64$ & 1 & $-11-13$ \\
\hline Throat discomfort & 4 & 25 & 3 & 10 & 2 & 6 & 19 & $-3-42$ & 4 & $-8-18$ \\
\hline Lower airway discomfort & 8 & 50 & 5 & 17 & 5 & 14 & 36 & $9-63$ & 3 & $-14-21$ \\
\hline $\begin{array}{l}\text { Skin discomfort } \\
\text { (itching/eczema) }\end{array}$ & 4 & 25 & 2 & 7 & - & 0 & 26 & $3-44$ & 7 & $-6-14$ \\
\hline
\end{tabular}

Table 4. Physiological parameters for workers exposed to dust from medium-density fiber board (MDF group) and traditional board (wood dust group) and a reference group $\left(\mathrm{v}_{2}=\right.$ the angle of the nasal breathing flow curve and is a measure of nasal resistance to breathing, $F V C=$ forced vital capacity, $F E V_{1.0}=$ forced vital capacity in $1 \mathrm{~s}$ )

\begin{tabular}{|c|c|c|c|c|c|c|c|c|c|c|c|}
\hline \multirow{3}{*}{ Group } & \multicolumn{2}{|c|}{ Olfactometry } & \multicolumn{3}{|c|}{ Rhinomanometry } & \multicolumn{2}{|c|}{$\begin{array}{l}\text { Impaired } \\
\text { mucociliary } \\
\text { clearance }\end{array}$} & \multicolumn{4}{|c|}{ Spirometry (I) } \\
\hline & \multirow{2}{*}{ Mean } & \multirow{2}{*}{ Range } & \multirow{2}{*}{$\begin{array}{c}\mathrm{v}_{2} \text { before } \\
\text { decon- } \\
\text { gestion }\end{array}$} & \multirow{2}{*}{$\begin{array}{l}v_{2} \text { after } \\
\text { decon- } \\
\text { gestion }\end{array}$} & \multirow{2}{*}{$\begin{array}{c}\text { Change } \\
\text { in } v_{2}\end{array}$} & \multirow{2}{*}{$\mathbf{N}$} & \multirow{2}{*}{$\%$} & \multicolumn{2}{|c|}{ FVC } & \multicolumn{2}{|c|}{$\mathrm{FEV}_{1.0}$} \\
\hline & & & & & & & & Expecte & Measured & Expecte & leasured \\
\hline $\begin{array}{l}\text { MDF } \\
(N=16)\end{array}$ & 13.9 & $6-18$ & 22.6 & 14.0 & 8.6 & - & 0 & 5.55 & $4.60^{* \cdots}$ & 4.39 & $3.67^{* * *}$ \\
\hline $\begin{array}{l}\text { Wood dust } \\
(N=29)\end{array}$ & 14.5 & $12-18$ & 21.0 & 13.4 & 7.6 & 5 & 17 & 5.46 & $4.89 * * *$ & 4.35 & $3.83^{* \cdots *}$ \\
\hline $\begin{array}{l}\text { Reference } \\
(\mathrm{N}=36)\end{array}$ & 15.6 & $10-20$ & 20.4 & 14.2 & 6.2 & 1 & 3 & 4.72 & 4.54 & 3.81 & 3.70 \\
\hline
\end{tabular}

$\because * P<0.001$. 
Table 5. Histological findings in the workers exposed to dust from medium-density fiber board (MDF group) and traditional fiber board (wood dust group) and the referents according to Torjussen's grading scale between $0-8$ (13).

\begin{tabular}{|c|c|c|c|c|c|}
\hline \multirow{2}{*}{ Group } & \multicolumn{3}{|c|}{ Biopsy score } & \multicolumn{2}{|c|}{$\begin{array}{l}\text { Goblet cell } \\
\text { hyperplasia }\end{array}$} \\
\hline & Mean & SD & Range & $N$ & $\%$ \\
\hline $\begin{array}{l}\text { MDF }(N=14) \\
\text { Wood dust }(N=26) \\
\text { Reference }(N=32)\end{array}$ & $\begin{array}{l}1.79 \\
2.35 \\
1.56\end{array}$ & $\begin{array}{l}1.05 \\
1.44 \\
0.88\end{array}$ & $\begin{array}{l}0-4 \\
0-6 \\
0-4\end{array}$ & $\begin{array}{r}- \\
4 \\
2\end{array}$ & $\begin{array}{r}0 \\
15 \\
6\end{array}$ \\
\hline
\end{tabular}

The nasal mucociliary clearance was pathological, slow, or absent in five of 24 workers $(17 \%)$ of the wood dust group, in one of 36 workers in the reference group, but in none of the MDF group.

Olfactometry showed a lower mean value of the sense of smell in the MDF group than in the wood dust group (table 4). The difference between the two groups was, however, not statistically significant, but in comparison with the reference group both of the exposed groups had significant deterioration of the sense of smell ( $\mathrm{P}<0.01$ for both groups).

The FVC values were lower than expected in both of the exposed groups. In the wood dust group the mean FVC value was 4.891 in comparison with the expected $5.46 \mathrm{l}$. This difference was statistically significant $(P<0.001, t=5.22)$. For the MDF group the mean FVC value was 4.601 and the corresponding expected value was $5.55 \mathrm{l}$. This difference was also statistically significant $(P<0.001, t=6.57)$. For the reference group there was no significant difference in comparison with the expected values.

In the wood dust group the $\mathrm{FEV}_{1.0}$ was decreased; the mean was $3.83 \mathrm{l}$, in comparison with the expected value of $4.35 \mathrm{l}$. This difference was statistically significant $(P<0.001)$. In the MDF group the mean $F V_{1.0}$ was 3.671 in comparison with the expected value of $4.39(\mathrm{P}<0.001)$. In the reference group the measured mean $\mathrm{FEV}_{1.0}$ was $3.70 \mathrm{l}$ and the expected was $3.81 \mathrm{l}$, the difference not being significant. The FEV \% $\left.\left[100 \cdot \mathrm{FEV}_{1.0}\right) / \mathrm{FVC}\right]$ was 79.7 (expected value 79 ) \% for the MDF group, 78.2 (79.7 expected) $\%$ for the wood dust group, and 81.4 (80.7 expected) $\%$ for the reference group. Thus the values were close to the expected level in all three groups.

Histological specimens were obtained from 14 workers in the MDF group and from 24 members of the wood dust group. Both groups had more histological changes than the reference group. In the wood dust group more severe histological findings were seen. There were two cases of dysplasia, whereas in the MDF group no dysplasia was seen. The mean score, according to Torjussen et al (13), was 1.79 (SD 1.05, range $0-4$ ) for the MDF group and 2.35 (SD 1.44, range $0-6)$ for the wood dust group (table 5). The difference in the mean score between the exposed groups was not statistically significant $(Z=1.02)$. Goblet cell hyperplasia was seen in 4 of 24 persons in the wood dust group, but in none of the workers in the MDF group.

\section{Discussion}

In this study workers handling MDF board had more symptoms of the upper airways, especially of the nose and eyes, than those persons working with traditional fiber board and pure wood. The symptoms were, however, more reversible in the MDF group. Airway symptoms were more frequent in both of the exposed groups than in the reference group.

No statistically significant difference was found between the exposed groups regarding physiological variables such as olfactory threshold and rhinomanometry. Rhinomanometry disclosed, however, more pronounced mucosal swelling in the MDF group that might contribute to nasal obstruction and decreased sense of smell. There was even, according to the threshold test, a decreased sense of smell in the MDF group in comparison with the wood dust group. On the other hand the mean age in the MDF group was somewhat higher, and this difference might have contributed to the result.

Formaldehyde has evoked interest in recent years with respect to its health effects, especially since it was found that formaldehyde is a nasal carcinogen in rodents (14). Epidemiologic studies $(15,16)$ and histological examination of nasal tissue from exposed humans (6) have not given evidence that formaldehyde provokes nasal cancer in man. Formaldehyde is a potential irritant to the mucous membranes in mainly the upper airways (4) and has been shown to interfere with the sense of smell, nasal mucociliary clearance, and pulmonary function of exposed workers (5).

As shown in table 1, exposure to both wood dust and formaldehyde was higher during work with MDF board. These figures are, however, based on only three whole-day measurements in each group, and conclusions in this respect are therefore risky. The higher exposure to formaldehyde and wood dust in the MDF group had little effect on the level of exposure to formaldehyde and wood dust in this group over the whole year, since none of the group members worked entirely with MDF board. Their total exposure was determined mainly by exposure to other wood material that they were working with themselves or were exposed to from the surroundings. All of the studied workers were mainly using the same type of machines and materials (other than MDF board). There is therefore no reason to believe that the findings concerning nasal symptoms could be explained by other differences in exposure than MDF. Thus we did not find any differences between the groups with respect to physiological properties of the dust, such as particle size (table 2).

If there is more formaldehyde released from the carbamide resin glue in the MDF board than from other fiber board, the difference could explain the higher incidence of symptoms in the MDF group, as proposed by Tell et al (17), who found that MDF board contains more formaldehyde than traditional fiber board. They also found that more wood dust, especially fine 
particle dust, is released during the cutting (milling) of MDF board than during the cutting of pure wood such as beech or traditional fiber board (17), and this finding is consistent with the results of the present study (table 1).

The occurrence of more wood dust in the MDF process, is important, not the least for the lower airways, which are unprotected if the dust is $<5 \mu \mathrm{m}$ in diameter (ie, respirable dust). Most dust particles in the furniture industry are $>5 \mu \mathrm{m}$ in diameter and are thus deposited in the nose. Respirable dust might interfere with lung function, and in this study there was a remarkable reduction in the FVC of both groups. However, the reduction was more severe in the MDF group. FVC reduction has also been reported for workers exposed long term to formaldehyde (5), and in this study all of the workers had exposure to formaldehyde released from MDF board or traditional fiber board to a certain degree.

In both exposed groups we also found a reduction in $\mathrm{FEV}_{1.0}$, but a normal FEV \%, a finding which might also indicate slight airway obstruction, consistent with the findings of Alexandersson et al (18) from formaldehyde-exposed workers and of Hedenstierna et al (19) from construction workers exposed to asbestos. These results could thus be interpreted as mixed restrictive and obstructive patterns (20).

The possibility of more fine particle dust being released from MDF board, in combination with exposure to formaldehyde absorbed on the dust particles, could explain the higher frequency of symptoms in the MDF group. However, since the whole-year exposure levels to formaldehyde and wood dust did not differ between the groups, we could not expect differences in the physiological parameters between the groups.

Histology gave no proof of more severe histological alterations in the MDF group than in the wood dust group. Two cases of dysplasia were found, both in the wood dust group and both in workers exposed long term to high doses of wood dust from grinding wood for $>4 \mathrm{~h} / \mathrm{d}$. These findings are consistent with those of other studies of nasal biopsies from workers in the furniture industry $(2,21)$.

Thus far, no proof is available that MDF is more hostile to the nasal or pulmonary tissues after longterm exposure, even though the nasal symptoms are more pronounced after short-time exposure than they are after exposure to wood dust or traditional fiber board.

\section{References}

1. Wilhelmsson B, Drettner B. Nasal problems in wood furniture workers - a study of symptoms and physiological variables. Acta Otolaryngol (Stockh) 1984;98: 548-55.

2. Wilhelmsson B, Lund B. Nasal epithelium in wood workers in the furniture industry - a histological and cytological study. Acta Otolaryngol (Stockh) 1984;98: 321-34.

3. Acheson ED. Nasal cancer in the furniture and boot and shoe manufacturing industries. Prev Med 1976;5:295315.

4. Gibson JE, ed. Formaldehyde toxicity. Washington, DC: Hemisphere Publishing Corporation, 1983.

5. Holmström M, Wilhelmsson B. Respiratory symptoms and pathophysiological effects of occupational exposure to formaldehyde and wood dust. Scand J Work Environ Health 1988;14:306-11.

6. Holmström M, Wilhelmsson B, Hellqvist $H$, Rosén $G$. Histological changes in the nasal mucosa in persons occupationally exposed to formaldehyde alone and in combination with wood dust. Acta Otolaryngol (Stockh) 1989;107:120-9.

7. Rosén G. Skapar MDF-board nya arbetsmiljöproblem i träindustrin? [Does MDF cause new work environmental problems in wood industry?]. In: Tampere Regional Institute of Occupational Health. Proceedings of the 34th Nordic occupational health meeting. Tampere (Finland): Tampere Regional Institute of Health, 1985: 134-5.

8. Vale PT, Rycroft RJG. Occupational irritant contact dermatitis from fibre board containing urea formaldehyde resin. Contact Dermatitis 1988;19:62.

9. Kumlien J, Schiratzki H. Methodological aspects of rhinomanometry. Rhinology 1979;17:107-14.

10. Broms P, Jonson B, Lamm CJ. Rhinomanometry: a system for numerical description of the nasal airway resistance. Acta Oto Laryngol (Stockh) 1982;94:157-68.

11. Amoore JE, Ollman BG. Practical test kits for quantitatively evaluating the sense of smell. Rhinology 1983; 21:49-54.

12. Berglund E, Birath G, Bjure J, Kjellmer J, Sandqqvist L, Söderholm B. Spirometric studies in normal subjects. Acta Med Scand 1963;173:185-98.

13. Torjussen W, Solberg LA, Høgetveit AC. Histopathological changes of the nasal mucosa in active and retired nickel workers. Cancer 1979;44:963-74.

14. Kerns WD, Pavkov KL, Donofrio DJ, Gralla EJ, Swenberg JA. Carcinogenicity of formaldehyde in rats and mice after long-term inhalation exposure. Cancer Res 1983;43:4382-92.

15. Blair A, Stewart P, O’Berg M, et al. Mortality among industrial workers exposed to formaldehyde. J Natl C $n$ cer Inst 1986;76:1071-84.

16. Vaughan TL, Strader C, Davis S, Dalin JR. Formaldehyde and cancers of the pharynx, sinus and nasal cavity: II. residential exposures. Int J Cancer 1986;38: 685-8.

17. Tell B, Kjellgren LG, Justsuk E. Dammalstring och arbetsmiljöförhållanden vid bearbetning av MDF-skivor [Dust generation and working environment conditions when machining MDF sheets]. Jönköping (Sweden): Swedish Institute for Wood Technology Research, 1983.

18. Alexandersson R, Kolmodin-Hedman B, Hedenstierna G. Exposure to formaldehyde: effects on pulmonary function. Arch Environ Health 1982;37:279-83.

19. Hedenstierna G, Alexandersson R, Kolmodin-Hedman B, Szamosi A, Tollqvist J. Pleural plaque and lung function in construction workers exposed to asbestos. Eur J Respir Dis 1981;62:111-22.

20. West J. Respiratory physiology - the essentials. 2nd ed. Baltimore, MD: Williams \& Williams Corp, 1980: 144-5.

21. Boysen M, Voss $\mathbf{R}$, Solberg LA. The nasal mucosa in soft wood exposed furniture workers. Acta Otolaryngol (Stockh) 1986;101:501-18.

Received for publication: 5 July 1990 